\title{
Dampak Perceraian Terhadap Kenakalan Remaja
}

\author{
Hendra Cipta \\ Jurusan Syariah \\ STAIN Syaikh Abdurrahman Siddik Bangka Belitung \\ Bangka, Indonesia \\ hendracipta80@yahoo.com
}

Abstract

In General, factors causing the emergence of juvenile deliquency are a family reason caused by divorce, both parents and the next factor is the environmental factors influenced by playmates and the environment around the dwelling. The media also have a role to cause juvenile delinquency. To minimize this juvenile delinquency that needs to be done is to enforce the rules, listen to teenagers complaints, give attention to teenagers, provide motivation to the teenagers and accompany and play with teenagers' activities they enjoy.

Key Words: Divorce, Jevenile Deliquency

Abstrak

Secara umum, faktor penyebab munculnya kenakalan remaja adalah alasan keluarga yang disebabkan oleh perceraian, kedua orang tua dan faktor berikutnya adalah faktor lingkungan yang dipengaruhi oleh teman bermain dan lingkungan di sekitar tempat tinggal. Media juga memiliki peran untuk menyebabkan kenakalan remaja. Untuk meminimalkan kenakalan remaja yang perlu dilakukan adalah menegakkan aturan, mendengarkan keluhan remaja, memberikan perhatian kepada remaja, memberikan motivasi kepada remaja dan menemani dan bermain dengan kegiatan remaja yang mereka nikmati.

Kata Kunci: Perceraian, Kenakalan Remaja

\section{A. Pendahuluan}

Orang tua berperan penting dalam membentuk karakter anak karena lingkungan pertama yang akan dilalui anak adalah lingkungan keluarga, sehingga harmonisnya hubungan orang tua (bapak dan ibu) serta orang tua dan anak akan ikut mempengaruhi mental dan pembentukan karakter anak sejak dini. ${ }^{1}$ Baik dan harmonisnya hubungan bapak dan ibu dalam keluarga tentu akan membuat mental dan karakter anak tumbuh berkembang dengan baik karena anak tidak menyaksikan pertengkaran orang tuanya dan komunikasi orang tua dengan anak tidak dipengaruhi emosi kemarahan setelah adanya pertengkaran bapak dan ibu.

Anak yang tumbuh dalam lingkungan keluarga broken home biasanya akan mengalami gangguan psikologis dan secara terus-menerus akan membentuk karakter negatif dan akhirnya memunculkan kenakalan di masa remaja. Kenakalan remaja ini ada yang berkaitan dengan kriminal dan ada yang tidak berkaitan dengan perbuatan kriminal, misalnya membolos di jam sekolah, kasar dan tidak sopan kepada orang tua dan lainnya. Keluarga broken home adalah keluarga yang tidak harmonis dan nyaman dalam kehidupannya karena berbagai sebab,

${ }^{1}$ M. Yusuf, MY., "Dampak Perceraian Orang Tua terhadap Anak”, Jurnal Al-Bayan, Vol. 20, No. 29, Januari-Juni 2014, hlm. 33. 


\section{| HENDRA CIPTA | Dampak Perceraian Terhadap Kenakalan Remaja}

diantaranya karena perceraian, ekonomi dan perang dingin atau cekcok antara anggota keluarga. ${ }^{2}$

Dyah Ayu Retnowulan dan Hadi Warsito menemukan bahwa faktor utama yang menyebabkan kenakalan remaja di sekolah adalah masalah keluarga yang tidak harmonis. Sementara kenakalan remaja yang diteliti adalah kenakalan remaja yang tidak berkaitan dengan tindakan kriminal baik dalam lingkungan sekolah maupun di luar lingkungan sekolah. Di antara kenakalan remaja nonkriminal dalam sekolah adalah membolos, mengintimidasi teman sekolah, membuat ribut di dalam kelas, tidak sopan dan berkelahi dengan teman sekolah. Sementara kenakalan remaja non-kriminal di luar sekolah adalah berbicara dan berperilaku kasar, berkendaraan dengan mengebut di jalanan, dan membuang sampah tidak pada tempatnya. ${ }^{3}$

Paramitha Dhatu Anindyajati dalam penelitiannya menemukan bahwa remaja yang belum mencapai status identitasnya setelah masa remaja akhir karena adanya hambatan yang mengganggu perkembangannya (misalnya perceraian orang tua) akan memunculkan remaja nakal dalam tingkat kenakalan menengah dan berat. ${ }^{4}$ Oleh karena itu lingkungan keluarga yang kurang harmonis dan broken home harus diperbaiki sedini mungkin agar tidak mengganggu tumbuh kembang anak dan remaja apalagi masa remaja adalah proses mencari identitas dan jati diri.

Generasi unggul mutlak diperlukan sebagai penerus pembangunan di suatu negara. Generasi yang unggul akan memunculkan sumber daya manusia yang tangguh dalam suatu negara. Keunggulan yang dimaksud tidak hanya dari sisi intelektual, tapi keunggulan tersebut juga tercermin dalam perilaku dan karakter serta hati nurani. ${ }^{5}$ Embrio untuk memunculkan generasi unggul tersebut sudah

\footnotetext{
2 Dyah Ayu Retnowulan dan Hadi Warsito, "Penerapan Strategi Pengelolaan Diri (Self Management) untuk Mengurangi Kenakalan Remaja Korban Broken Home”, Jurnal BK Unesa, Vol.03, No. 01, 2013, hlm. 336.

${ }^{3}$ Ibid., hlm. 337-338.

${ }^{4}$ Paramitha Dhatu Anindyajati, "Status Identitas Remaja Akhir: Hubungannya dengan Gaya Pengasuhan Orang Tua dan Tingkat Kenakalan Remaja", Character, Vol. 01, No. 02, Tahun 2013, hlm. 5.

5 Harun Rasyid, "Membangun Generasi Melalui Pendidikan Sebagai Investasi Masa Depan”, Jurnal Pendidikan Anak, Vol. IV, Edisi 1, Juni 2015, hlm. 566.
} 


\section{| HENDRA CIPTA | Dampak Perceraian Terhadap Kenakalan Remaja}

harus dimulai dari masa anak-anak dan remaja, karena masa ini merupakan masa yang sangat menentukan dalam membentuk dan mengarahkan potensi seseorang.

\section{B. Remaja}

Remaja adalah proses transformasi individu dari masa kanak-kanak menuju kepada masa dewasa. Seseorang dikatakan remaja jika sudah mempunyai kematangan dalam hal mental, emosional, sosial dan fisik. ${ }^{6}$

Berdasarkan pembagian usia, masa remaja terbagi kepada tiga macam periodesasi kelompok usia, yaitu:

1. Masa Pra Pubertas, fase ini terdiri dari usia 9 sampai dengan 11 tahun. Pada fase ini merupakan fase transisi dari anak-anak menuju remaja, karena dalam kategori usia ini seseorang disebut anak-anak tapi sudah melewati batas usia anak-anak dan disebut remaja tapi belum mencapai kategori usia remaja. Secara fisik fase ini ditandai dengan berubahnya suara dan pada bagian-bagiaan tubuh tertentu ditumbuhi oleh rambut.

2. Masa Pubertas, fase ini terdiri dari usia 14 sampai dengan 15 tahun. Ciri-ciri fase ini adalah remaja sudah mulai familiar dengan lingkungan sekitar dan kehidupan sosial di luar rumah serta lebih sering berada di luar rumah karena berkumpul dengan temantemannya.

3. Masa Pasca Pubertas, fase ini terdiri dari usia 17 sampai dengan 19 tahun. Fase ini ditandai dengan ketertarikan remaja kepada lawan jenisnya dan mulai memperhatikan penampilannya. ${ }^{7}$

Remaja merupakan periode kehidupan seseorang dari umur 12 sampai dengan 21 tahun, periode remaja ini ditandai dengan kematangan seseorang dalam berfikir dan ditandai dengan kematangan serta kedewasaan emosional, hal inilah yang membedakan antara remaja dengan anak-anak. Masa anak-anak adalah

\footnotetext{
${ }^{6}$ Paramitha Dhatu Anindyajati, "Status Identitas ...., hlm. 2.

${ }^{7}$ Hurlock, Psikologi Perkembangan Suatu Pendekatan Sepanjang Rentang Kehidupan, edisi ke-IV, (Jakarta: Erlangga, 1990), hlm. 206-207.
} 


\section{| HENDRA CIPTA | Dampak Perceraian Terhadap Kenakalan Remaja}

periode umur 3 sampai dengan 11 tahun dan anak-anak belum mempunyai kematangan berfikir serta emosional sebagaimana layaknya remaja.

Lebih jauh Dwi Anita Alfiani mengutip Sarlito Wirawan Sarwono mengungkapkan bahwa masa remaja ditandai dengan proses pembentukan jati diri, mulai berkembangnya inteligensi, mulai berkembangnya peran seseorang dalam kehidupan sosial serta mulai berkembangnya peran dari sisi gender, kualitas religiusitas dan moral seseorang. ${ }^{8}$

\section{Perceraian}

Perceraian dalam fiqih dikenal dengan istilah talaq yang secara bahasa bermakna melepaskan dan secara istilah adalah melepaskan tali pernikahan dan memutuskan ikatan perkawinan. ${ }^{9}$ Efek dari terjadinya talak ini adalah putusnya ikatan perkawinan antara pihak suami dan istri yang terikat dalam ikatan perkawinan yang sah.

Dalam pasal 116 Kompilasi Hukum Islam perceraian terjadi karena berbagai sebab:

1. Salah satu di antara suami maupun istri melakukan perbuatan zina, mabuk, judi dan perbuatan lainnya yang sulit untuk disembuhkan.

2. Pihak suami atau pihak istri meninggalkan salahsatunya dalam rentang waktu dua tahun berturut-turut tanpa ada alasan.

3. Salah satu pihak yang terikat ikatan perkawinan mendapatkan hukuman dan dikurung penjara selama waktu lima tahun maupun hukuman yang lebih berat.

4. Satu di antara dua pihak yang terikat ikatan perkawinan melakukan kekerasan berat dan membahayakan keselamatan pihak lain.

5. Salah satu di antara pihak suami atau istri menderita penyakit kronis yang tidak mungkin disembuhkan dan menjadikan dia tidak bisa menjalankan kewajibannya sebagai suami maupun istri.

${ }^{8}$ Dwi Anita Alfiani, "Kajian Teoritis terhadap Perkembangan Psikis Anak dan Remaja", http://www.syekhnurjati.ac.id/jurnal/index.php/awlady/article/view/742/598, diakses tanggaal 1 Juli 2017, hlm. 6-7.

${ }^{9}$ Sayyid Sabiq, Fiqh Sunnah, (Lebanon: Dar al-Fikr, 1995), hlm. 162. 


\section{| HENDRA CIPTA | Dampak Perceraian Terhadap Kenakalan Remaja}

6. Terus terjadi pertikaian dan pertengkaran di antara pasangan suami dan istri serta tidak mungkin untuk didamaikan lagi dalam kehidupan rumah tangga.

7. Pihak suami melakukan pelanggaran yang terdapat dalam taklik talak.

8. Murtadnya salah satu pihak di antara suami maupun istri. ${ }^{10}$

Perceraian dalam kehidupan rumah tangga bisa disebabkan oleh beberapa faktor, Hanif Nur Rohman pada penelitian yang dilakukannya di Surakarta menemukan faktor penyebab terjadinya perceraian adalah:

1. Komunikasi yang tidak baik antara suami dan istri sehingga menyebabkan sering terjadi pertengkaran dalam kehidupan rumah tangga. Kurangnya komunikasi antara suami dan istri juga menyebabkan kurangnya perhatian dari salah satu pihak.

2. Tidak setianya salah satu pasangan baik suami maupun istri. Ketidaksetiaan yang dilakukan oleh salah satu pasangan diwujudkan dalam bentuk perselingkuhan. Perceraian biasanya timbul karena pasangan yang diselingkuhi tidak menerima telah diselingkuhi atau pelaku selingkuh yang meninggalkan pasangannya dan lebih memilih pasangan selingkuhannya.

3. Kekerasan Dalam Rumah Tangga (KDRT), hal ini bisa dalam bentuk fisik maupun non fisik, misalnya menyakiti pasangan dengan cacian dan makian (dalam bentuk verbal) dan pasangan yang tersakiti tidak menerima telah disakiti dan menuntut untuk bercerai.

4. Faktor ekonomi, dengan gaya hidup modern biasanya membutuhkan materi yang banyak dan ketika pasangan hidup tidak mampu memenuhi kebutuhan materi tersebut akhirnya memilih perceraian karena ketidakpuasan terhadap pasangan dari sisi memenuhi kebutuhan ekonomi.

${ }^{10}$ http://e-dokumen.kemenag.go.id/files/tdTAsFc51315881487.pdf, diakses tanggal 21 Juli 


\section{| HENDRA CIPTA | Dampak Perceraian Terhadap Kenakalan Remaja}

5. Munculnya masalah dalam kehidupan berumah tangga, kadang-kadang permasalahan kecil bisa menjadi besar ketika pasangan suami dan istri tidak menyikapinya dengan dewasa, akhirnya menyulut pertengkaran dan akibatnya bercerai. ${ }^{11}$

Perceraian kedua orang tua dari sisi hukum tanpa mengindahkan hak asuh anak dan hak nafkah anak akan berdampak kepada anak khususnya dari sisi hakhak anak, oleh karena itu jangan sampai masa depan anak-anak terampas dengan kesalahan kedua orang tuanya yang melakukan perpisahan dan perceraian perkawinan. Berdasarkan Keputusan Presiden Nomor 36 Tahun 1990 dijelaskan hak-hak anak mencakup:

1. Hak untuk kelangsungan hidup.

2. Hak untuk dilindungi.

3. Hak untuk diawasi dan dibimbing tumbuh kembang optimalnya.

4. Hak partisipasi. ${ }^{12}$

\section{Kenakalan Remaja}

Kenakalan remaja atau dikenal juga dengan juvenile delinquency selalu ada di tengah masyarakat, problem kenakalan remaja berkembang seiring sejak terbentuk dan berkembangnya masyarakat, masalah kenakalan remaja ini muncul karena berbagai faktor, bisa dari lingkungan sosial maupun karena faktor kultural. ${ }^{13}$ Tidak peduli apakah di lingkungan yang religius maupun tidak.

Kenakalan remaja merupakan perbuatan melanggar hukum, bertentangan dengan norma sosial, asusila serta bertentangan dengan aturan-aturan agama yang dilakukan oleh remaja. Kenakalan remaja ini tidak hanya identik dengan tindakan

11 Hanif Nur Rohman, "Dampak Perceraian Terhadap Kualitas Hubungan Orang Tua Dengan Anak di Surakarta (Studi Deskriptif Kualitatif Tentang Dampak Perceraian Terhadap Kualitas Hubungan Orang Tua dengan Anak di Surakarta)", Skripsi, Jurusan Sosiologi Fakultas Ilmu Sosial dan Ilmu Politik Universitas Sebelas Maret Surakarta, 2011, hlm. 96-97.

12 Anjar S C Nugraheni, et.al., "Komparasi Hak Asuh dan Hak Nafkah dalam Putusanputusan Perceraian di Pengadilan Negeri dan Pengadilan Agama Kota Surakarta", Yustisia, edisi 87, September-Desember 2013, hlm. 62-63.

13 Ahmad Syafii, et.al, "Pengaruh Narkoba Terhadap Kenakalan Remaja di Sulawesi Tengah”, Media Litbang Sulteng 2 (2), Desember 2009, hlm. 87. 


\section{| HENDRA CIPTA | Dampak Perceraian Terhadap Kenakalan Remaja}

kriminal, perbuatan melanggar norma sosial dan agama juga bisa dikatakan dengan kenakalan remaja. Kenakalan remaja ini terbagi kepada empat macam:

1. Kenakalan yang dilakukan oleh remaja yang mengakibatkan korban mengalami cidera fisik, misalnya tawuran yang dilakukan oleh remaja yang menyebabkan orang lain terluka.

2. Kenakalan yang dilakukan oleh remaja yang menyebabkan korban mengalami kerugian berupa materi, misalnya remaja melakukan pencurian yang mengakibatkan korban pencurian kehilangan uang.

3. Kenakalan sosial yaitu kenakalan yang dilakukan oleh remaja yang tidak ada korban dari pihak manapun atau bisa dikatakan juga dengan kenakalan amoral, misalnya perbuatan berbohong yang dilakukan oleh remaja.

4. Kenakalan karena keinginan remaja melawan status. Misalnya seorang remaja melawan orang tua karena tidak terima dengan status orang tuanya, perlawanan tersebut dilakukan dengan pergi dari rumah orang tua. $^{14}$

Paramitha Dhatu Anindyajati yang mengutip Steinberg membagi kenakalan kepada tiga bagian, yaitu:

1. Tingkat kenakalan berat meliputi pemerkosaan dan pembunuhan.

2. Tingkat kenakalan sedang meliputi mencuri, merampok, menodong, dan merampas.

3. Tingkat kenakalan ringan meliputi bolos sekolah dan meninggalkan rumah tanpa izin. ${ }^{15}$

Sebagian psikolog menyatakan kenakalan remaja adalah suatu yang lumrah terjadi karena masa remaja adalah masa dimana seseorang tidak mau

\footnotetext{
${ }^{14}$ Muh. Abdus Sofa, "Hubungan Pola Asuh Orang Tua dengan Kenakalan Remaja Pada Siswa-Siswi SMA Negeri 1 Kepohbaru Bojonegoro", Tesis Koleksi Fakultas Psikologi Universitas Islam Negeri Maulana Malik Ibrahim Malang, http://etheses.uinmalang.ac.id/593/6/10410063\%20Bab\%202.pdf, diakses tanggal 2 Juli 2017.

${ }^{15}$ Paramitha Dhatu Anindyajati, "Status Identitas ...., hlm.3.
} 


\section{| HENDRA CIPTA | Dampak Perceraian Terhadap Kenakalan Remaja}

menerima aturan-aturan yang memberikan batasan bagi kebebasannya dalam mengekspresikan sikap. Dikarenakan hal-hal seperti ini banyak remaja dikatakan nakal dan tidak taat aturan. Dalam kondisi psikologis seperti ini seharusnya peran orang tua penting dalam membimbing para remaja menghadapi "pemberontakan batinnya". 16

Indonesia sebagai negara yang mempunyai penduduk terbanyak dibandingkan dengan anggota ASEAN lainnya tentu harus lebih giat membentengi penduduknya (khususnya generasi muda) dari "gangguan" budaya dan peradaban asing seiring semakin bebasnya akses informasi dan teknologi di masing-masing negara ASEAN. Sebagai negara dengan penduduk mayoritas muslim, Indonesia tentunya harus tetap menjaga dan memelihara nilai-nilai Islam masih dihayati dan diamalkan oleh generasi muda Indonesia (khususnya remaja).

Masa remaja adalah periode yang menentukan bagi masa depan seseorang karena pada masa inilah keputusan dalam menghadapi tantangan hidup harus diakomodasi dengan tepat. Karena pada masa ini remaja akan menghadapi perubahan biologis pada dirinya, mengembangkan keterampilan emosional yang baru dan mulai harus mengatur diri sendiri. Jika tantangan-tantangan ini tidak diatasi dengan bijak dan tepat, maka besar kemungkinan remaja tersebut akan mengalami depresi di masa perkembangannya. ${ }^{17}$

Masa remaja juga merupakan masa bagi otak terus mengalami pematangan. Ukuran otak terus akan mengalami perubahan setelah usia awal masuk sekolah. Oleh karena itu, pada tahap pematangan otak ini para remaja harus dihindari dari berbagai macam gangguan yang akan menghambat proses pematangan otaknya. Salah satu faktor yang akan mempengaruhi perkembangan otak remaja menjadi tidak sehat adalah faktor lingkungan, jika seorang remaja

16 Nunung Unayah dan Muslim Sabarisman, "Fenomena Kenakalan Remaja dan Kriminalitas", Sosio Informa, Vol. 1, No. 2, Mei - Agustus 2015, hlm. 123.

17 Dominique F. Maciejewski, et.al., "The Development of Adolescent Generalized Anxiety and Depressive Symptoms in The Context of Adolescent Mood Variability and ParentAdolescent Negative Interaction", J Abnom Child Psychol, 2014, hlm. 515. 


\section{| HENDRA CIPTA | Dampak Perceraian Terhadap Kenakalan Remaja}

tumbuh pada lingkungan yang terbiasa dengan tindakan kriminal, maka kemungkinan besar remaja tersebut juga akan menjadi pelaku kriminal. ${ }^{18}$

Salah satu bentuk dari pengaruh negatif faktor lingkungan adalah fenomena Lesbian, Gay, Biseksual dan Transgender (LGBT) yang sekarang sedang menjadi isu hangat di Indonesia. Menurut Astry Budiarty perilaku homoseksual banyak terjadi di usia remaja yang disebabkan oleh kurangnya interaksi dengan kawan yang berbeda jenis kelamin dan kurangnya pergaulan. Pelaku homoseksual ini awalnya adalah pemuda yang normal, namun karena pengaruh lingkungan yang hanya berinteraksi antar sesama jenis mengakibatkan pemuda normal tersebut menjadi pelaku homoseksual. ${ }^{19}$ Vindi Septyanti Wulandari pada penelitiannya menyatakan seseorang yang sering bergaul dengan orang-orang yang berperilaku menyimpang, maka lambat laun orang tersebut akan ikut melakukan perilaku menyimpang ${ }^{20}$

Media juga mempunyai peranan dalam mempengaruhi perkembangan remaja. Joseph T. Klapper (dalam Edy Susena dan Dewi Amelia Lestari) menyatakan terdapat teori belajar pada efek media, artinya seseorang belajar berbuat sesuatu melalui media yang diamatinya. Misalnya seorang remaja yang dibiarkan menonton film laga di televisi, maka ada kemungkinan dia akan menirukan gerakan-gerakan laga dari film yang disaksikannya. ${ }^{21}$ Bahkan, tidak jarang seorang anak dan remaja ingin menjadi seseorang yang disaksikannya di televisi, seperti ingin menjadi Superman, Batman dan lain sebagainya.

\footnotetext{
${ }^{18}$ Sunita Bava dan Susan F. Tapert, “ Adolescent Brain Development and The Risk for Alcohol and Other Drug Problems", Neuropsychol Rev, 2010, hlm. 399.

${ }^{19}$ Lebih jauh Astry menyatakan ada tiga faktor yang menyebabkan seseorang menjadi lesbian, yaitu: (1) Pengaruh keadaan keluarga dan kondisi hubungan orang tua yang kurang harmonis, (2) Pengalaman seksual yang buruk pada masa anak-anak, (3) Pengaruh lingkungan. Dikutip dari Astry Budiarty, "Gaya Hidup Lesbian (Studi Kasus di Kota Makasar)", Skripsi, Koleksi Jurusan Sosiologi Fakultas Ilmu Sosial dan Ilmu Politik Universitas Hasanuddin Makasar, 2011, hlm. 29 dan 36-37.

${ }^{20}$ Vindi Septyanti Wulandari, "Perilaku Seksual Penyuka Sesama Jenis Perempuan atau Lesbi di Kota Palembang (Studi pada Komunitas Lesbi IABSS di Kota Palembang), Skripsi, Jurusan Sosiologi Fakultas Ilmu Sosial dan Ilmu Politik Universitas Sriwijaya, 2013.

21 Edy Susena dan Dewi Amelia Lestari, "Dampak Penggunaan Internet terhadap Kecerdasan Pelajar Sekolah Menengah Atas (SMA) di Daerah Pedesaan dalam Rangka Peningkatan Kualitas Pendidikan di Daerah Pedesaan", Jurnal Saintech Politeknik Indonusa Surakarta, Vol. 2, No. 2, 2014, hlm. 3.
} 


\section{| HENDRA CIPTA | Dampak Perceraian Terhadap Kenakalan Remaja}

Faktor-faktor penyebab munculnya kenakalan remaja dalam penelitian Rahman Taufiqrianto Dako adalah:

1. Lingkungan keluarga, keluarga yang tidak harmonis adalah salah satu penyebab munculnya kenakalan remaja. Orang tua yang tidak memperhatikan dan akrab dengan anak menyebabkan anak depresi dan tidak patuh terhadap orang tua. Orang tua harus menjadi panutan bagi anak dan remaja jangan sampai anak tidak menjadikan orang tuanya sebagai panutan karena orang tua tidak memberikan contoh yang baik bagi anak.

2. Teman bermain baik yang sebaya maupun yang tidak sebaya. Jika anak bergaul dengan teman bermain yang tidak baik maka kemungkinan anak tersebut bisa menjadi tidak baik pula, misalnya teman bermain anak adalah pecandu game online, maka besar kemungkinan anak akan jarang di rumah karena sering bermain game online dengan temantemannya di warnet yang kemungkinan juga tidak mengenal waktu siang dan malam.

3. Lingkungan masyarakat yang tidak ramah terhadap anak dan remaja akan membentuk anak menjadi tidak solider, walaupun dari lingkungan keluarga sudah mengajarkan solidaritas, namun ketika hidup dalam lingkungan yang tidak solider akan mempengaruhi perilaku anak menjadi nakal.

4. Media masa baik media cetak maupun media elektronik. Anak yang sering menonton film laga akan mempengaruhi karakter anak tersebut karena dia berkeinginan menjadi seperti pahlawan super yang ditontonnya. Kecanggihan teknologi pada saat ini membuat anak mudah menjangkau informasi baik dari media cetak maupun media elektronik. $^{22}$

${ }^{22}$ Rahman Taufiqrianto Dako, "Kenakalan Remaja”, Jurnal Inovasi, Vol. 9, No. 2, Juni 2012, hlm. 4-6. 


\section{| HENDRA CIPTA | Dampak Perceraian Terhadap Kenakalan Remaja}

Intaglia Harsanti dan Dwi Gita Verasari dalam penelitian mereka menemukan faktor utama penyebab kenakalan remaja adalah faktor keluarga dan faktor lingkungan. Keretakan keluarga yang berakibat pada perceraian adalah indikator utama dari faktor keluarga, tidak jarang ketika orang tua bercerai membuat remaja yang orang tuanya bercerai menjadi malu dan tidak menerima keputusan bercerai yang diambil kedua orang tuanya. ${ }^{23}$ Namun, perlu dicatat bahwa tidak semua anak korban perceraian orang tuanya akan menjadi anak dan remaja nakal.

\section{E. Solusi Bagi Kenakalan Remaja Akibat Perceraian Orang Tua}

Orang tua mempunyai peran penting dalam membentuk dan membangun karakter anak, setidaknya ada lima faktor yang menyatakan peran orang tua tersebut:

1. Keyakinan yang dianut oleh orang tua.

2. Watak dan karakter orang tua.

3. Latar belakang pendidikan orang tua.

4. Motivasi dan pegangan hidup orang tua.

5. Riwayat perjalanan dan perjuangan orang tua dalam menjalani kehidupan.

Faktor lain yang juga mempengaruhi terbentuknya karakter anak, yaitu: (1) lingkungan sekitar anak, baik di lingkungan masyarakat maupun sekolah. (2) kondisi lingkungan internal keluarga anak tersebut. ${ }^{24}$

Orang tua juga mempunyai peran dalam membentuk perilaku sosial dan emosional anak. ${ }^{25}$ Orang tua yang memberikan kesempatan kepada anak untuk berinteraksi dengan lingkungan sosial di sekitarnya akan membentuk perilaku

${ }^{23}$ Intaglia Harsanti dan Dwi Gita Verasari, "Kenakalan pada Remaja yang Mengalami Perceraian Orang Tua", Proceeding PESAT (Psikologi, Ekonomi, Sastra, Arsitektur dan Teknik Sipil), Vol. 5, Bandung, 8-9 Oktober 2013, hlm. 75.

24 Ahmad Yani, et.al., "Implementasi Islamic Parenting dalam Membentuk Karakter Anak Usia Dini di RA At-Taqwa Kota Cirebon", Awlady: Jurnal Pendidikan Anak, Vol.3, No.1, Maret 2017, hlm. 163

25 Jaja Suteja dan Yusriah, "Dampak Pola Asuh Orang Tua terhadap Perkembangan Sosial-Emosional Anak", Awlady: Jurnal Pendidikan Anak, Vol.3, No.1, Februari 2017, hlm. 3. 


\section{| HENDRA CIPTA | Dampak Perceraian Terhadap Kenakalan Remaja}

sosial anak yang adaptif terhadap lingkungan sosial di sekitarnya dan orang tua yang mendidik anaknya dengan penuh kasih sayang dan tidak mengutamakan kemarahan dan ancaman akan membentuk kematangan emosi yang stabil bagi anak.

Ada istilah golden age sebagai periodesasi dalam membentuk intelektual dan karakter anak, golden age ini berada di antara usia 0-4 tahun karena pada usia ini pertumbuhan otak dan kecerdasan anak mencapai $50 \% .{ }^{26}$ Peranan orang tua sangat diperlukan pada golden age ini karena anak usia 0-4 tahun lebih banyak berhubungan dengan orang tua di rumah daripada dengan lingkungan sekitar, sehingga lingkungan belum banyak mempengaruhi pada golden age ini.

Namun, bagi anak dan remaja yang orangtuanya telah berpisah dari ikatan perkawinan tentu saja sulit bagi anak dan remaja tersebut untuk dapat perhatian bapak dan ibunya dalam waktu bersamaan. Maka, yang harus dilakukan oleh orang tua yang sudah bercerai terhadap kenakalan yang dilakukan anaknya walaupun dilakukan secara terpisah oleh bapak maupun ibu anak dan remaja tersebut adalah:

1. Tegakkan aturan bagi anak, membiasakan anak disiplin dengan peraturan yang dibuat oleh orang tua walaupun orang tuanya telah berpisah membuat anak akan disiplin dengan aturan dan norma-norma kebaikan dimanapun dia berada.

2. Bertanya kepada anak apa yang menyebabkan dia melakukan kenakalan. Mungkin saja anak dan remaja punya alasan tertentu yang membuat dia melakuan kenakalan dan orang tua harus peka terhadap masalah yang dihadapi oleh anaknya dan mau mendengarkan masalah yang dihadapi oleh anaknya.

3. Bantu anak dalam meredakan amarahnya. Anak dan remaja tingkat kematangan emosi mereka belum mumpuni, maka orang tua berperan penting membantu anak dan menemukan cara bagi anak dan remaja

${ }^{26}$ Gifari Annisa Rohani, "Pengaruh Televisi (TV) terhadap Aspek-aspek Perkembangan Anak Usia 3-4 Tahun", Jurnal Pendidikan Anak, Vol. IV, Edisi 2, Desember 2015, hlm. 635. 


\section{| HENDRA CIPTA | Dampak Perceraian Terhadap Kenakalan Remaja}

dalam mengatasi dan mengontrol diri mereka ketika dalam keadaan marah.

4. Memberikan perhatian yang lebih terhadap anak. Orang tua yang sudah bercerai harus mampu mengalahkan ego mereka masing-masing demi memberikan perhatian lebih terhadap anak, jangan dibiarkan anak korban perceraian orang tua tidak didampingi dalam mengarungi masa remaja yang banyak menghadapi tantangan psikologis dalam kehidupannya.

5. Orang tua harus mengetahui kesenangan anak dan ikut mendampingi anak dan remaja mereka dalam melakuan kegiatan yang disenanginya. Misalnya anak laki-laki senang bermain bola basket, maka bapak anak tersebut harus ikut mendampingi anak laki-lakinya dalam kegiatan olah raga basket apakah ikut bermain atau berdiskusi dengan anak tentang dunia basket.

6. Hindari mengejek anak dan remaja. Ketika anak dan remaja mengalami masalah, maka orang tua jangan sampai mengejek atau bahkan mencela, melainkan orang tua harus mampu memberikan motivasi untuk menguatkan anak dan remaja dalam menghadapi masalah. $^{27}$

\section{F. Kesimpulan}

Masa remaja adalah masa seseorang perlu mendapatkan perhatian dan pendampingan karena pada tahap ini adalah tahap transisi seseorang dari masa anak-anak kepada masa dewasa. Pada tahap ini juga seseorang memperoleh pengalaman penting untuk membentuk karakternya ketika menghadapi masa dewasa. Sehingga walaupun kedua orang tua telah bercerai, kedua orang tua tersebut tetap harus mendampingi tumbuh kembang anak remajanya walaupun pendampingan tersebut tidak dilakukan bersamaan dalam satu waktu dan bertemu langsung secara bersamaan antara bapak, ibu dan anak remaja.

${ }^{27}$ Nunung Unayah dan Muslim Sabarisman, "Fenomena Kenakalan Remaja ...., hlm. 135 


\section{DAFTAR PUSTAKA}

Alfiani, Dwi Anita, "Kajian Teoritis terhadap Perkembangan Psikis Anak dan Remaja",http://www.syekhnurjati.ac.id/jurnal/index.php/awlady/article/vie w/742/598, diakses tanggaal 1 Juli 2017.

Anindyajati, Paramitha Dhatu, "Status Identitas Remaja Akhir: Hubungannya dengan Gaya Pengasuhan Orang Tua dan Tingkat Kenakalan Remaja", Character, Vol. 01, No. 02, Tahun 2013.

Bava, Sunita dan Susan F. Tapert, "Adolescent Brain Development and The Risk for Alcohol and Other Drug Problems", Neuropsychol Rev, 2010.

Budiarty, Astry, "Gaya Hidup Lesbian (Studi Kasus di Kota Makasar)”, Skripsi, Koleksi Jurusan Sosiologi Fakultas Ilmu Sosial dan Ilmu Politik Universitas Hasanuddin Makasar, 2011.

Dako, Rahman Taufiqrianto, "Kenakalan Remaja”, Jurnal Inovasi, Vol. 9, No. 2, Juni 2012.

Harsanti, Intaglia dan Dwi Gita Verasari, "Kenakalan pada Remaja yang Mengalami Perceraian Orang Tua", Proceeding PESAT (Psikologi, Ekonomi, Sastra, Arsitektur dan Teknik Sipil), Vol. 5, Bandung, 8-9 Oktober 2013.

Hurlock, Psikologi Perkembangan Suatu Pendekatan Sepanjang Rentang Kehidupan, edisi ke-IV, Jakarta: Erlangga, 1990.

http://e-dokumen.kemenag.go.id/files/tdTAsFc51315881487.pdf, diakses tanggal 21 Juli 2017.

Maciejewski, Dominique F., et.al., "The Development of Adolescent Generalized Anxiety and Depressive Symptoms in The Context of Adolescent Mood Variability and Parent-Adolescent Negative Interaction", J Abnom Child Psychol, 2014.

Nugraheni, Anjar S C, et.al., "Komparasi Hak Asuh dan Hak Nafkah dalam Putusan-putusan Perceraian di Pengadilan Negeri dan Pengadilan Agama Kota Surakarta”, Yustisia, edisi 87, September-Desember 2013.

Rasyid, Harun, "Membangun Generasi Melalui Pendidikan Sebagai Investasi Masa Depan”, Jurnal Pendidikan Anak, Vol. IV, Edisi 1, Juni 2015. 


\section{| HENDRA CIPTA | Dampak Perceraian Terhadap Kenakalan Remaja}

Retnowulan, Dyah Ayu dan Hadi Warsito, "Penerapan Strategi Pengelolaan Diri (Self Management) untukk Mengurangi Kenakalan Remaja Korban Broken Home”, Jurnal BK Unesa, Vol.03, No. 01, 2013.

Rohani, Gifari Annisa, "Pengaruh Televisi (TV) terhadap Aspek-aspek Perkembangan Anak Usia 3-4 Tahun", Jurnal Pendidikan Anak, Vol. IV, Edisi 2, Desember 2015.

Rohman, Hanif Nur, "Dampak Perceraian Terhadap Kualitas Hubungan Orang Tua Dengan Anak di Surakarta (Studi Deskriptif Kualitatif Tentang Dampak Perceraian Terhadap Kualitas Hubungan Orang Tua dengan Anak di Surakarta)", Skripsi, Jurusan Sosiologi Fakultas Ilmu Sosial dan Ilmu Politik Universitas Sebelas Maret Surakarta, 2011.

Sabiq, Sayyid, Fiqh Sunnah, Lebanon: Dar al-Fikr, 1995.

Sofa, Muh. Abdus, "Hubungan Pola Asuh Orang Tua dengan Kenakalan Remaja Pada Siswa-Siswi SMA Negeri 1 Kepohbaru Bojonegoro", Tesis Koleksi Fakultas Psikologi Universitas Islam Negeri Maulana Malik Ibrahim Malang, http://etheses.uinmalang.ac.id/593/6/10410063\%20Bab\%202.pdf, diakses tanggal 2 Juli 2017.

Susena, Edy dan Dewi Amelia Lestari, "Dampak Penggunaan Internet terhadap Kecerdasan Pelajar Sekolah Menengah Atas (SMA) di Daerah Pedesaan dalam Rangka Peningkatan Kualitas Pendidikan di Daerah Pedesaan”, Jurnal Saintech Politeknik Indonusa Surakarta, Vol. 2, No. 2, 2014.

Suteja, Jaja dan Yusriah, "Dampak Pola Asuh Orang Tua terhadap Perkembangan Sosial-Emosional Anak", Awlady: Jurnal Pendidikan Anak, Vol.3, No.1, Februari 2017.

Syafii, Ahmad, et.al, "Pengaruh Narkoba Terhadap Kenakalan Remaja di Sulawesi Tengah", Media Litbang Sulteng 2 (2), Desember 2009.

Unayah, Nunung dan Muslim Sabarisman, "Fenomena Kenakalan Remaja dan Kriminalitas", Sosio Informa, Vol. 1, No. 2, Mei - Agustus 2015.

Wulandari, Vindi Septyanti, "Perilaku Seksual Penyuka Sesama Jenis Perempuan atau Lesbi di Kota Palembang (Studi pada Komunitas Lesbi IABSS di Kota Palembang), Skripsi, Jurusan Sosiologi Fakultas Ilmu Sosial dan Ilmu Politik Universitas Sriwijaya, 2013.

Yani, Ahmad, et.al., "Implementasi Islamic Parenting dalam Membentuk Karakter Anak Usia Dini di RA At-Taqwa Kota Cirebon", Awlady: Jurnal Pendidikan Anak, Vol.3, No.1, Maret 2017. 
| HENDRA CIPTA | Dampak Perceraian Terhadap Kenakalan Remaja

Yusuf, M., MY., "Dampak Perceraian Orang Tua terhadap Anak”, Jurnal AlBayan, Vol. 20, No. 29, Januari-Juni 2014. 